Special Article

\title{
My Tribute to Evandro de Oliveira
}

\author{
Hung Tzu Wen ${ }^{1}$ \\ ${ }^{1}$ Faculdade de Medicina da Universidade de São Paulo, São Paulo/SP, \\ Brazil
}

Arq Bras Neurocir 2021;40(1):12-13.

When I think of Dr. Evandro de Oliveira, the overwhelming feeling is gratitude, as he changed my career and my life to beyond my wildest expectations.

I met Dr. Evandro in 1990 when he joined the Division of Neurosurgery of Hospital das Clínicas at University of São Paulo Medical School as head of vascular neurosurgery, and I was a $3^{\text {rd }}$ year resident. He was the rising star in neurosurgery, that was all I knew about him at that time. Soon, everything we used to do in the operating room changed, starting from the layout of the tables, the position of the surgical personnel and the microscope, a plastic bag was added to make the patient draping waterproof, hemostats for stopping the bleeding from the skin were replaced by meticulous coagulation using bipolar forceps; interfascial dissection for preserving frontal branch of the facial nerve, the use of fish hooks for retraction, the location of each burr hole and the standardized pterional approach were presented. Sharp dissection of the sylvian fissure and basal cisterns, and the use of bipolar forceps, microscissors, and suction tubes of different lengths became routine practice. Foot and mouth switches for surgeon were introduced to control the microscope without withdrawing the hands from the surgical field; hydraulic surgical stools became part of surgeon's armamentarium. It was the beginning of the era of anatomy-based microsurgery in our institution, a mesmerizing experience for me.

He was the neurosurgeon who best understood and applied the philosophies of two giants in neurosurgery: the neuroanatomical school of Dr. Albert L. Rhoton Jr., and the microsurgery school of Dr. M Gazi Yasargil. For him, neurosurgery is about passion and art: surgery is not merely a manual task, it is a piece of art, and depending on how you devote your attention to it, your surgery can become a masterpiece.

Address for correspondence Hung Tzu Wen, MD, PhD, Faculdade de Medicina da Universidade de São Paulo, São Paulo/SP, Brazil (e-mail: wenht@uol.com.br).
DOI https://doi.org/ 10.1055/s-0041-1730270. ISSN 0103-5355.
I soon picked him as my role model in neurosurgery; I wanted to follow his footsteps, I wanted to be like him.

After finishing my residency program, I became his fellow, and I had the opportunity to closely learn from him for 7 months. Because of his recommendation, I became research fellow of Dr. Rhoton, where I spent 2,5 years of intense learning in neuroanatomy; after 6 months of fellowship, Dr. Evandro invited me to help him to design a new course "Sulci Gyri and Ventricles"; the course turned out to be successful, but I remember the stress and the fear- I did not want to fail him.

I returned to Brazil in 1996 and I started working with him in his private practice and at Hospital das Clínicas as member of epilepsy and vascular teams, position that I hold to date.

Over the years, even after I left his private practice in 2001, he continued to give me opportunities to travel with him, to attend meetings, and to help him in his courses around the world. I always was impressed to see how respected he was, no matter where we were.

He was known for being firm and determined, he always stood by what he believed was right, but at the same time, he was very generous too. Not only did he help me, but he also helped and inspired many other disciples from different parts of the world, especially from the countries he most visited: Argentina, Bolivia, Chile, China, Colombia, Italy, Japan, Mexico, Paraguay, Portugal, Russia, Spain, South Korea, Taiwan, Turkey, Uruguay, and USA. They fully understood his philosophy e they have successfully applied it in their daily practice. He has certainly saved and changed the lives of thousands of patients, directly and indirectly.

We kept our friendship with a lot of respect for each other throughout the years. In my weekly visit to him during his illness, we talked for hours about anything - politics, future Neurosurgery meetings, the stock market, Covid-19, etc. We (c) 2021. Sociedade Brasileira de Neurocirurgia. All rights reserved. This is an open access article published by Thieme under the terms of the Creative Commons Attribution-NonDerivative-NonCommercial-License, permitting copying and reproduction so long as the original work is given appropriate credit. Contents may not be used for commercial purposes, or adapted, remixed, transformed or built upon. (https://creativecommons.org/ licenses/by-nc-nd/4.0/) Thieme Revinter Publicações Ltda., Rua do Matoso 170, Rio de Janeiro, RJ, CEP 20270-135, Brazil 
also talked about the good memories we shared from our gastronomy tours in different countries. However, he was especially happy, and in his element when I showed him some difficult cases, and he would help me with his enormous knowledge and wisdom.

It has been truly a great honor and privilege for me to be his disciple, to work under his guidance, and to have his friendship for more than 30 years. Dr. Evandro is gone, but his guiding light (as his middle name "Luz" means) remains. Please, watch over us.

With my eternal admiration and thankfulness.

Conflict of Interest

None. 